\title{
Rotating bed reactor packed with heterofunctional structured silica-supported lipase or Novozym 435. Developing an effective system for the organic solvent and aqueous phase reactions
}

\author{
Katarzyna Szymańska ${ }^{1}$, Daria Kowalczykiewicz ${ }^{2}$, Danuta Gillner ${ }^{1}$, and Andrzej Jarzębski ${ }^{1}$ \\ ${ }^{1}$ Politechnika Śląska Wydział Chemiczny \\ ${ }^{2}$ Politechnika Slaska Wydzial Chemiczny
}

July 31,2020

\begin{abstract}
Production of specialty chemicals increasingly makes use of enzyme catalysts, and Novozym 435 (N435) is among most often applied. However, its polymeric skeleton is unstable in many solvents. In this context, we report results of a systematic study of the biocatalysts, fabricated using highly porous siliceous pellets/enzyme (MH), grafted with octyl (-O), amino (-A) and octyl and amino (-OA) groups, deployed in a rotating bed reactor and tested in hydrolysis and esterification reactions. N435 appeared the most active in both reactions, when activity was related to the catalyst's mass, mainly owing to very large enzyme load. But its structure degraded in many typical solvents, whereas no such effect was detected in MH-O- and MH-OA-catalysts. MH-O showed the highest specific activity, however, a significant enzyme leaching was observed in a hydrolytic reaction, in contrast to MH-OA. In esterification reaction the MH-O-bound lipase was not only most active but also quite stable.
\end{abstract}

Rotating bed reactor packed with heterofunctional structured silica-supported lipase or Novozym 435. Developing an effective system for the organic solvent and aqueous phase reactions

Daria Kowalczykiewicz ${ }^{1,2}$, Katarzyna Szymańska ${ }^{3 *}$, Danuta Gillner ${ }^{1,2}$, Andrzej B. Jarzębski ${ }^{3,4}$

1. Department of Organic Chemistry, Bioorganic Chemistry and Biotechnology, Silesian University of Technology, B. Krzywoustego 4, 44-100 Gliwice, Poland

2. Biotechnology Center, Silesian University of Technology, B. Krzywoustego 8, 44-100 Gliwice, Poland

3. Department of Chemical Engineering and Process Design, Silesian University of Technology, Ks. M. Strzody 7, 44-100 Gliwice, Poland

4. Institute of Chemical Engineering, Polish Academy of Sciences, Bałtycka 5, 44-100 Gliwice, Poland

Funding: This work was supported by the by the National Centre for Science - Poland, project UMO2016/23/B/ST8/00627.

Abstract : Production of specialty chemicals increasingly makes use of enzyme catalysts, and Novozym 435 (N435) is among most often applied. However, its polymeric skeleton is unstable in many solvents. In this context, we report results of a systematic study of the biocatalysts, fabricated using highly porous siliceous pellets/enzyme (MH), grafted with octyl (-O), amino (-A) and octyl and amino (-OA) groups, deployed in a rotating bed reactor and tested in hydrolysis and esterification reactions. N435 appeared the most active in both reactions, when activity was related to the catalyst's mass, mainly owing to very large enzyme load. But its structure degraded in many typical solvents, whereas no such effect was detected in MH-O- and 
MH-OA-catalysts. MH-O showed the highest specific activity, however, a significant enzyme leaching was observed in a hydrolytic reaction, in contrast to MH-OA. In esterification reaction the MH-O-bound lipase was not only most active but also quite stable.

Keywords: silica beads, lipase catalyst, Novozym 435, rotating bed reactor, dedicated catalysts INTRODUCTION

Supreme catalytic properties of enzymes offer an efficient and environmentally friendly strategy for the production of value-added chemicals, under mild conditions. Owing to good stability in diverse media, promiscuity in recognition different substrates and regioselectivity in both hydrolysis and inter-, trans/esterification reactions in organic media, lipases emerge as the biocatalysts of prime importance (Foukis et al., 2017; Thomas, Burich, Bandeira, Marques de Oliveira \& Piovan, 2017; Zare, Golmakani \& Niakousari, 2019). For practical reasons: easy separation, reusability and increased stability, the industry favours the use of immobilized enzymes (Dwivedee, Bhaumik, Rai, Laha \& Banerjee, 2017; Mallin, Muschiol, Byström \& Bornscheuer, 2013; Odrozek et al. 2017; Szymańska, Bryjak, Mrowiec-Białon \& Jarzębski, 2007; Szymańska, Odrozek, Zniszczoł, Pudło \& Jarzębski, 2017). In industrial applications, the most common of lipase-based biocatalysts is the Novozym 435 (N435), i.e. Candida antartica lipase B (CALB) adsorbed on a hydrophobic macroporous acrylic resin - the Lewatit VP OC 1600 (Foukis et al., 2017; Goundoju, Bokam, Yalavarthi, Shaik \& Ponnapalli, 2019; Huang et al., 2019; Ortiz et al., 2019; Tang, Wang, Huang, Jin \& Wang, 2015; Thomas, Burich, Bandeira, Marques de Oliveira \& Piovan, 2017; Wang, Gu, Cui, Wu \& Wu, 2014; Wang et al., 2016; Zare, Golmakani \& Niakousari, 2019). Its particle size below $1 \mathrm{~mm}$, renders it a good candidate to be used in both stirred tank- (STR) and packed bed (PBR) reactors (Foukis et al., 2017; Thomas, Burich, Bandeira, Marques de Oliveira \& Piovan, 2017; Wang, Gu, Cui, Wu \& Wu, 2014). However, despite a widespread application, N435 exhibits a number of important negative features that are usually ignored, as pointed out by others group (Ortiz et al. 2019; Jose, \& Briand, 2010; Jose et al., 2011; Zhao \& Song, 2010). Owing to weak binding forces of adsorption, the leakage of proteins thus attached to the carrier can easily be triggered by a small change in temperature, $\mathrm{pH}$ and ionic strength, or even the presence of substrates and solvents. Moreover, fragility of the Lewatit particles, results in their comminution under mechanical stirring, and this gives rise to serious separation problems and also facilitates the enzyme leaching, that is often disregarded. And not less importantly, the Lewatit matrix dissolves in many organic solvents (Ortiz et al., 2019), and this leads to migration of monomers or larger entities to the liquid phase (Jose et al., 2011) Zhao \& Song listed in this context 17 substances that migrated from N435 towards organic solvents and ionic liquids, and some of them even turned out to be active as acyl donors in the esterification and transesterification reactions (Zhao \& Song, 2010). All these observations clearly evidence the kind of problems that may occur when N435 is used either in STR or in organic media, or both.

In the PBRs the catalysts load is much larger than in STRs, and that leads to higher values of space-time yield (STY), and hence improved process economy. Additionally, mass transfer to the catalysts particles can also be more intensive, provided that fluid velocities are high. But the latter implies the need for a high backpressure, and hence endangers safety. A rational engineering solution may be the use of rotating bed reactors (RBRs), that allow for a simultaneous mixing and percolation of reactants through the bed of heterogeneous catalysts placed in a cylindrical basket, mounted at the end of the shaft (Aurell, Karlsson, Ponten, \& Andersen, 2014; Mallin, Muschiol, Byström \& Bornscheuer, 2013; Szymańska, Odrozek, Zniszczoł, Pudło \& Jarzębski, 2017). The problems of catalysts damage and separation are removed, and the tortuous interconnected channels between the particles can induce intensive lateral mixing and much enhanced mass transfer, which boost the overall reaction rate (Xu et al., 2017). Moreover, similarly as in PBRs the catalysts load can be high, and it translates into high values of STY, without compromising process safety. For these reasons, the RBRs attract increasing attention and were recently applied in a number of practical situations: hydrogenation of D-xylose to D-xylitol, using ruthenium decorated carbon foam (Pham et al., 2016), lipase catalyzed regioselective lactamization (Aurell, Karlsson, Ponten, \& Andersen, 2014), selective fractionation of hemicellulose and lignin (Eta, Anugwom, Virtanen, Maki-Arvela \& Mikkola, 2014) or hardwood (Eta \& Mikkola, 2016), and (S)-naproxen synthesis using immobilized decarboxylase (Aßmann et al., 2017). 
A limitation for the RBR application is posed by the size of catalyst particles - it needs to be larger than ca. 0.4 mm (Aurell, Karlsson, Ponten, \& Andersen, 2014; Mallin, Muschiol, Byström \& Bornscheuer, 2013; Szymańska, Odrozek, Zniszczoł, Pudło \& Jarzebski, 2017), and this eliminates the use of the most common mesoporous silica materials as enzyme supports, but N435 meets this condition. A rational option for the RBR application may be the use of silica beads/pellets which possess an open, optimally hierarchical meso-macropore structure, that is stable in various solvents, can easily be functionalized to attach enzymes and allow for an unhindered transport of reactants to the catalytic sites. These relatively new materials proved to be very effective as continuous flow monolithic microreactors (Helm, 2019; Hou et al., 2019; Strub, Szymańska, Hrydziuszko, Bryjak \& Jarzebski, 2019; Szymańska et al. 2013; Szymańska et al., 2016a; Szymańska et al., 2016b), and also as $3 \mathrm{~mm}$ sized enzyme-activated packing of RBRs, applied in sucrose hydrolysis (Szymańska, Odrozek, Zniszczoł, Pudło \& Jarzebski, 2017) and oxidation of benzoic acid (Odrozek et al., 2017). Not less importantly, unlike polymeric enzyme supports, the siliceous beads could be regenerated and reused several times, with no change in the pore structure.

In contrast to the extensive studies of mesoporous silica as enzyme carriers (Hudson, Cooney \& Magner, 2008), reports on the use of macroporous siliceous carriers are scarce (Jiang et al., 2016; Zhou et al., 2008), and we are familiar only with the study of matrices with macropores ca. $0.5 \mu \mathrm{m}$ dia. and small mesopores, ca. $5 \mathrm{~nm}\left(0.5 \mathrm{~cm}^{3} \mathrm{~g}^{-1}\right.$ mesopore volume). Meanwhile, the silica beads developed recently in our group (Odrozek et al., 2017; Szymańska, Odrozek, Zniszczoł, Pudło \& Jarzebski, 2017), feature much more open structure, an extensive $\left(3 \mathrm{~cm}^{3} \mathrm{~g}^{-1}\right.$ pore volume) network of macropores $20-40 \mu \mathrm{m}$ in diameter, and mesopores of about $20 \mathrm{~nm}$ and $1 \mathrm{~cm}^{3} \mathrm{~g}^{-1}$ pore volume. This makes them easily penetrable, and hence potentially very attractive, especially that the size of macropores in the packed bed enzyme carriers was found to be critical for highly active catalytic beds (Szymańska, Odrozek, Zniszczoł, Pudło \& Jarzebski, 2017). Note, that owing to both thermal and chemical stability of the silica, contamination of the reaction mixture with degradation products is nonexistent. Moreover, silanol groups allow for a facile grafting of its surface with various functional groups to attach strongly the enzyme, and also other moieties which stimulate expression of high enzymatic activity (Hou et al., 2019; Odrozek et al, 2017; Strub, Szymańska, Hrydziuszko, Bryjak \& Jarzebski, 2019; Szymańska et al. 2013; Szymańska et al., 2016a; Szymańska et al., 2016b; Szymańska, Odrozek, Zniszczoł, Pudło \& Jarzebski, 2017).

To prevent enzyme leakage, either an ionic or a covalent bonding of the enzyme by means of various organosilanes is recommended. More recently, it evolved to apply hetero-, usually bi-functionalized carriers, the surface of which was decorated with hydrophobic groups - responsible for a proper conformation of lipase, and amino- or epoxy groups - that allow for a more stable bonding of the enzyme (Bernal, Illanes, \& Wilson, 2014; Hirata et al., 2016; Vescovi et al., 2016). The latter approach was also recently shown to enable a preferential orientation of proteins on the carrier, to make a full use of their catalytic potentials, and hence emerges as being more effective (Wang, Zhang, Han, Wu \& Wei, 2018).

Clearly, all these works pave the way to a new, integrated platform for the intensive synthesis of fine chemicals. Proceeding along this path, we considered it important to explore potentials of the RBRs filled with biocatalysts, obtained using structured porous silica beads, the surface of which was (hetero)functionalized to attach CALB, and to compare their performance, in both an aqueous- and organic solvent system, with that of the N435-packed same RBR. To obtain a deeper insight into the surface effects, the beads were functionalized either separately with octyl- and amino groups, or simultaneously with them both. The biocatalytic properties were studied in esterification of levulinic acid and hydrolysis of $p$ - nitrophenyl acetate. The former reaction attracts major interest since levulinic acid is a versatile renewable platform molecule of high chemical reactivity and its esters have various practical applications (Zhou et al., 2018). However, owing to a precarious behavior of the N435 in various organic solvents on one hand, and their widespread application on the other, prior to mainstream studies we deemed it important to investigate solvents effect on the N435 pore structure and catalytic activity after $24 \mathrm{~h}$ of soaking.

\section{MATERIALS AND METHODS}

2. Materials 
Hexadecyltrimethylammonium bromide (CTAB), $p$ - nitrophenyl acetate ( $p$ - NPA, 97\%) and Bengal Rose (85\%) were purchased from Acros Organics. Tetraethyl orthosilicate (TEOS, 98\%), polyethylene glycol 35000 (PEG), levulinic acid (98\%), lipase B from Candida antarctica , 3-aminopropyltrimetoxysilane and n-octyltrietoxysilane were obtained from Sigma Aldrich. Glutaraldehyde (GLA, 25\%) was from Avantor Performance Materials (Poland). Novozym 435 was kindly provided by Novozymes.

Fabrication of silica pellets

The siliceous pellets were prepared using methodology adapted from Szymańska (Szymańska, Odrozek, Zniszczoł, Pudło \& Jarzebski, 2017). Briefly, polyethylene glycol 35000 (PEG, $8.67 \mathrm{~g}$ ) was dissolved in 1M $\mathrm{HNO}_{3}(100 \mathrm{~mL})$. After that, tetraethyl orthosilicate (TEOS, $82.8 \mathrm{~mL}$ ) was added dropwise in an ice bath and then hexadecyltrimethylammonium bromide (CTAB, $3.8 \mathrm{~g})$. The solution was mixed and pipetted into small conical vessels $(50 \mu \mathrm{L})$, left to gel at $40^{\circ} \mathrm{C}$ and aged for 7 days. After that time the impregnation in ammonia solution $(1 \mathrm{M})$ was carried out for $9 \mathrm{~h}$ at $90^{\circ} \mathrm{C}$, and then the obtained pellets were washed with water, dried at room temperature and calcined at $550^{\circ} \mathrm{C}$ for $8 \mathrm{~h}$.

Functionalization of silica pellets

Briefly, $1 \mathrm{~g}$ of dry siliceous pellets was modified with amino groups using $0.27 \mathrm{~mL} 3$ aminopropyltrimethoxysilane, dissolved in $32.5 \mathrm{~mL}$ of dry toluene, and gently stirred and refluxed at 85 ${ }^{\circ} \mathrm{C}$, for $48 \mathrm{~h}$. Then the obtained pellets (MH-A) were dried on the air. To attach octyl groups, dry silica pellets $(1 \mathrm{~g})$ were gently stirred and refluxed with $0.49 \mathrm{~mL}$ of n-octyltriethoxysilane, dissolved in $32.5 \mathrm{~mL}$ dry toluene, at $85{ }^{\circ} \mathrm{C}$, for $48 \mathrm{~h}$. After that the pellets (MH-O) were dried similarly to MH-A. To attach both amino and octyl groups, $1 \mathrm{~g}$ of dry monolith carriers was gently stirred and refluxed with $0.24 \mathrm{~mL}$ n-octyltriethoxysilane and $0.13 \mathrm{~mL} 3$-aminopropylotrimethoxysilane dissolved in $32.5 \mathrm{~mL}$ of dry toluene, for $48 \mathrm{~h}$, at $85^{\circ} \mathrm{C}$, and then the pellets (MH-OA) were dried on the air.

Lipase immobilization on silica pellets

Prior to attachment of the lipase, pellets were washed with ethanol $\left(5 \mathrm{~h}, 50{ }^{\circ} \mathrm{C}\right)$, then with distilled water $(3$ x $30 \mathrm{~min} \times 30 \mathrm{~mL}$ ), and after that with $0.1 \mathrm{M}$ phosphate buffer ( $\mathrm{pH} 7.0 ; 3 \times 30 \mathrm{~min})$. Then the MH-O pellets were immersed in $30 \mathrm{~mL}$ of the lipase solution in $0.1 \mathrm{M}$ phosphate buffer $(\mathrm{pH} 7.0)$, for $2.5 \mathrm{~h}$, at $25^{\circ} \mathrm{C}$, and then left at $6{ }^{\circ} \mathrm{C}$ overnight. After that they were washed with $30 \mathrm{~mL}$ of $0.1 \mathrm{M}$ phosphate buffer (pH 7.0) for $30 \mathrm{~min}$, to remove excess proteins, and finally filtered and vacuum dried at $4{ }^{\circ} \mathrm{C}$. The amount of immobilized enzyme was determined with Lowry method, using bovine serum albumin as a standard. To attach the lipase on to $\mathrm{MH}-\mathrm{A}$ and $\mathrm{MH}-\mathrm{OA}$, the pellets were washed as described before, and then activated with glutaraldehyde ( $2.5 \%$ glutaraldehyde solution in $0.1 \mathrm{M}$ phosphate buffer, $\mathrm{pH}$ 7.0). Excess of glutaraldehyde was removed by washing with distilled water, then with $0.1 \mathrm{M}$ phosphate buffer $\mathrm{pH} 7(3 \times 30 \mathrm{~min} \times 30 \mathrm{~mL})$. Afterward, the pellets were immersed in the lipase solution as described for $\mathrm{MH}-\mathrm{O}$, and then treated in the same way.

\section{Characterization of supports}

The supports were characterized by elemental analysis (CHNS) using LECO model TruSpec Micro elemental analyzer and by FTIR spectroscopy, applying Nicolet iS50 instrument from Thermo Fisher Scientific. The pellets were grated with KBR ( $5 \%$ mass of sample). The mesopore structure of the carriers was determined by the nitrogen adsorption at $-196{ }^{\circ} \mathrm{C}$, using a Micromeritics ASAP 2020 instrument, and in meso- and macropore size range, by mercury porosimetry (Quantachrome Pore Master 60). The hydrophobicity of the modified pellets was determined by adsorption of Bengal Rose dye, using the method described by Vescovi [36] and Lima [38] (details are given in Supplementary Information).

Activity and stability of the biocatalysts in aqueous system and in organic solvent

All experiments were carried out using a commercial RBR (SpinChem) with $100 \mathrm{~mL}$ working volume. The hydrolysis activity of immobilized lipase was determined using the procedure described by Gustafsson et al. (Gustafsson, Thorn \& Holmberg, 2011). The enzyme-activated pellets (0.14 g) or $0.05 \mathrm{~g}$ N435 were placed in the reactor's basket. The substrate solution ( $15 \mathrm{~mL}$ of $p$ - nitrophenyl acetate in acetonitrile, $5.5 \mathrm{mM})$ 
dissolved in $50 \mathrm{mM}$ phosphate buffer $\mathrm{pH} 7(85 \mathrm{~mL})$ was placed in RBR. The reaction was carried out at 37 $\operatorname{deg} \mathrm{C}$, at rotation speed of $500 \mathrm{rpm}$. The amount of released $p$ - nitrophenol was measured spectrophotometrically at $400 \mathrm{~nm}$. The calibration curve was prepared using $p$ - nitrophenol as standard. The operational stability of the biocatalysts in aqueous media was checked in 4 runs. After each run the biocatalysts were washed with $50 \mathrm{mM}$ phosphate buffer $(\mathrm{pH} 7.0)$.

In the case of esterification of levulinic acid, $0.355 \mathrm{M}$ of levulinic acid and $0.710 \mathrm{M}$ of n-butanol were mixed with diisopropyl ether (total volume of $100 \mathrm{~mL}$ ), and incubated for $15 \mathrm{~min}$. at $50 \mathrm{degC}$. After that $1 \mathrm{~g}$ of the enzyme-activated pellets, or $0.24 \mathrm{~g}$ of N435, were placed in RBR basket and mixed at rotation speed of $500 \mathrm{rpm}$. The amount of n-butyl levulinate was determined using gas chromatography. The calibration curve was prepared using n- butyl levulinate as a standard. To evaluate the operational stability of the biocatalysts in organic solvent, the reaction was carried out four times. After each run the biocatalysts were washed with diisopropyl ether at room temperature.

To evaluate the stability of immobilized lipases in different organic solvents, $0.1 \mathrm{~g}$ of the catalyst was incubated with $1 \mathrm{~mL}$ of chosen organic solvent (acetonitrile, ethyl acetate, hexane, butanol, acetone and diisopropyl ether), at $37 \mathrm{degC}$ for $24 \mathrm{~h}$. Then the samples were dried under vacuum and enzymatic activity was measured using hydrolysis of $p$ - NPA as a standard reaction. Additionally, the N435 pore structure was examined by low temperature nitrogen adsorption and mercury porosimetry.

\section{RESULTS and DISCUSSION}

Our earlier studies (Szymańska, Odrozek, Zniszczoł, Pudło \& Jarzebski, 2017) showed that activity of the enzyme immobilized on silica pellets strongly depends on pore structure in the macropore size range. Thus, the catalysts with 20-40 $\mu \mathrm{m}$ (dia.) macropores proved to be much more active than those with $10 \mu \mathrm{m}$ pores or less, for the same (macro)pore volume. For this reason, in the reported studies, the applied lipase carriers (of conical shape) also had the very open pore structure, and external sizes of $5.1 \mathrm{~mm} \times 3.3 \mathrm{~mm}(\mathrm{H} / \mathrm{d}$ ). $\mathrm{Hg}$ porosimetry showed an ample presence of macropores 20-50 $\mathrm{m}$ in size (pore volume ca. $3 \mathrm{~cm}^{3} \mathrm{~g}^{-1}$ ) and mesopores 20-30 nm (volume ca. $1 \mathrm{~cm}^{3} \mathrm{~g}^{-1}$ ) (Fig.1). But SEM images also revealed the presence of even larger macropores interconnected in a tortuous network of flow-through channels (Fig.1). These images also very clearly show openness of the structure and accessibility of the internal surface. Large macropores and textural mesopores of the silica skeleton enabled unhindered penetration by various moieties. Modification of the surface appeared to affect porosity in the meso- but not macropore-size scales. The specific surface area ( $\mathrm{S}_{\mathrm{BET}}$, Table 1) of $310 \mathrm{~m}^{2} \mathrm{~g}^{-1}$ before modification decreased almost by half after amino groups implementation (MH-A), but only about $10 \%$ in the octyl group modified pellets (MH-O). The decrease in the pore volume and its size after functionalization was insignificant, but even then the modified carriers still offered large surface area easily accessible for both the enzyme molecules and reactants. Moreover, the applied RBR filled in one-third with the structured siliceous carriers offers the surface-to-volume ratio of over $10^{6} \mathrm{~m}^{2} \mathrm{~m}^{-3}$. That is at least an order of magnitude more than feature much acclaimed microreactors made of $100 \mu \mathrm{m}$ capillaries, the capacity of which is only a tiny fraction of the reactor used in these studies (Strub et al., 2019).

Chemical character of the surface is a critical property for enzyme immobilization. FTIR spectroscopy (Supporting Information, Fig. S1) was used to confirm the presence of functional moieties on the support's surface. The unmodified silica featured a broad band between $3200 \mathrm{~cm}^{-1}$ and $3600 \mathrm{~cm}^{-1}$ that could be ascribed to the $\mathrm{Si}-\mathrm{OH}$ stretching vibrations, additionally a sharp and intense band at $3740 \mathrm{~cm}^{-1}$, could be unambiguously assigned to the $\mathrm{OH}$ symmetric stretching vibration of isolated silanol groups (Karbowiak et al., 2010). Adsorption bands around $1000-1250 \mathrm{~cm}^{-1}$ and $800 \mathrm{~cm}^{-1}$ are attributed to asymmetric and symmetric stretching vibrations of the Si-O-Si framework (Ciemiega, Maresz \& Mrowiec-Białoń, 2018). Appreciable changes in all the spectra were observed after modification of the monolithic support with organic moieties. First, the intensity of the band at $3740 \mathrm{~cm}^{-1}$ was notably reduced due to incorporation of organic groups. The amino groups presence were identified by the methylene stretching bands of the propyl chain in the region of $2850-2950 \mathrm{~cm}^{-1}$, seen in FTIR spectra of both MH-A and MH-OA, and their deformation bands at $1410-1455 \mathrm{~cm}^{-1}$. The $\mathrm{N}-\mathrm{H}$ absorption bands overlapped with $\mathrm{O}-\mathrm{H}$ bands at $3200-3600$ 
$\mathrm{cm}^{-1}$ (Szymańska, Bryjak, Mrowiec-Białon \& Jarzebski, 2007). Methylene stretching bands of the octyl chain (MH-O) in the region of $2850-2950 \mathrm{~cm}^{-1}$ is poorly visible mostly because of small amount of the incorporated octyl groups.

The amount of functional group present on silica surface was calculated from elemental analysis data (Table 1) assuming complete hydrolysis and subsequent condensation of ethoxy or methoxy groups from organosilica precursor during functionalization. As can be seen (Table 1), the amount of octyl groups on silica surface was at least two times lower than that of amino groups, and this could be explained by much higher reactivity of methoxysilanes than ethoxysilanes.

For lipases, hydrophobicity of the support is of particular importance (Bernal, Illanes, \& Wilson, 2014; Garmroodi et al., 2016; Ortiz et al., 2019; Vescovi et al., 2016). In these studies, it was evaluated from the amount of a hydrophobic compound (Bengal Rose dye) adsorbed on the carrier. The chemical modification of the silica (Table 1) increased its capacity to adsorb the hydrophobic dye from $0.0149 \mathrm{mg} \mathrm{g}^{-1}$ (for pure silica MH) to $0.133,0.233$ and $0.311 \mathrm{mg} \mathrm{g}^{-1}$, respectively for MH-O, MH-A and MH-OA. For MH-A and $\mathrm{MH}-\mathrm{OA}$, the higher adsorption of Bengal Rose could be explained by an ionic interaction between ionized groups present in both the dye and the support (Vescovi et al, 2016). It is noteworthy that the amount of dye adsorbed on MH-OA approximately equals to an aggregate of values found for MH-A and MH-O. Thus, surface ability to adsorb Bengal Rose dye quite well correlates with the amount of the attached lipase (Table 1).

Owing to specific character of the applied functional groups, for each of the carriers the first step of lipase immobilization is adsorption on the support, and in the case of $\mathrm{MH}-\mathrm{A}$ and $\mathrm{MH}-\mathrm{OA}$ it is followed by a covalent stabilization of the enzyme by reactive moieties (amino groups) (Vescovi et al., 2016). Since CALB is the same enzyme as the one applied in N435, we could directly compare its content in all the catalysts. It is noteworthy that amino functionalized silica appeared to bound more enzyme than the silica grafted with octyl groups, owing to ionic forces which hugely impact the lipase immobilization yield. Thus not surprisingly, the largest amount of protein was attached to heterofunctionalized silica (MH-OA, $27 \mathrm{mg} / \mathrm{g}$ ). But even then, it was at least two times less than determined for N435 (Table 1).

Once the MH family of catalysts was prepared we investigated the effect of organic solvents treatment -24 h soaking - on catalytic activity, also of N435, and confronted it with the changes in its pore structure. As can be seen from Table 2 (and also Fig. S2 and Fig. S3, SI) even the most typical organic solvents appeared to exert a significant effect on pore structure of N435, and surprisingly enough, it appeared to be different in micrometer and nanometer scales. Only the diisopropyl ether slightly reduced porosity fairly symmetrically in both domains, in a stark contrast to butanol, acetonitrile and ethyl acetate, which caused a nearly total collapse of mesopores (Fig. S3, SI). First two of the latter solvents had little effect on the volume of very large pores (macropores), unlike ethyl acetate in which that volume nearly doubled, a clear sign of a significant restructuring and swelling of Lewatit (Fig.S3, SI). These structural changes of the polymeric support are likely to be accompanied with, and stimulate the release of various chemical entities to the solvent/reaction system, as was first reported by Zhao \& Song (2010) and most recently also by other authors (Jose \& Briand, 2010; Jose et al. 2011). In the reported study we did not tackle this issue in more detail.

Investigations of the catalysts activity after the solvent treatment showed (Table 2) that a hydrolytic activity of the N435 remained high, except for ethyl acetate and somewhat less acetonitrile, which proved to be detrimental. It can be observed that a notable decrease of N435 activity quite well correlates with major changes in pore structure of the polymeric support (Table 2, Fig. S2 and Fig. S3). However, the effect of organic solvents on catalytic activity of the supported enzymes is likely far more complex; we did not go much into these details. More importantly, in a stark contrast to N435 all of the functionalized silica-supported biocatalysts proved not susceptible to organic solvents, and they were consistently highly active (Table 2). Owing to some sort of a symmetrical effect on both enzyme carriers, the diisopropyl ether was selected to be used in a more systematic study of both N435 and the MH-series of biocatalysts.

First, the biocatalysts were tested in the hydrolysis of $p$ - nitrophenyl acetate in a phosphate buffer (pH 7.0) 
using RBR operating at $500 \mathrm{rpm}$ (centrifugal acceleration ca. $11.5 \mathrm{~g}$ ). In this reaction the highest activity showed N435, whereas activity of MH-O and MH-OA was lower, but much similar in value (Fig. 2A). Least active appeared to be MH-A, even though its enzyme load was comparable with MH-O. If however, the catalytic activity was related to the amount of the immobilized lipase, the most active appeared to be $\mathrm{MH}-$ $\mathrm{O}$, followed by MH-OA (Fig. 2B). This can be partly explained by much better accessibility of the lipase, but mainly by a hydrophobic character of the silica surface and its huge effect on conformation and hence activity of the attached lipase. The latter is usually termed as an 'interfacial activation' and it has been extensively studied before (Ortiz et al., 2019).

From a practical point of view, more important than catalyst's activity is its stability, and it was checked in four successive cycles. N435, MH-A and MH-O showed (Fig. 3) very good stability, whereas the MH-O attached lipase was strongly leaching from the carrier, and it is in accord with previous observations (Ortiz et al., 2019). Thus, a hydrophobic interaction between the lipase and the carrier, while essential for expressing lipase activity, was not strong enough to counter a water-protein affinity and also the effect of forces exerted by the flowing fluids. To conclude, taking into account the catalytic activity and stability, and also the lack of susceptibility to organic solvents, the heterofunctional MH-OA emerges as a rational option for the lipase-catalyzed hydrolytic reaction. Note that in RBRs the potentially lower catalytic activity can easily be compensated by much larger catalyst load (3.5 g of MH-type of catalysts in the applied reactor), so to give in effect very high values of space-time yield. For that packed with MH-OA catalyst the STY value was about $2 \mathrm{~g} \mathrm{~h}^{-1} \mathrm{~L}^{-1}$, and it is respectable.

Activity of the biocatalysts was also checked in the esterification of levulinic acid dissolved in diisopropyl ether (Fig. 4). Similarly as in the hydrolysis reaction the highest activity (per gram of catalyst) showed Novozym 435 (Fig. 4A); the one revealed by MH-O was notably lower but still more than twice the value of heterofunctional MH-OA, even though the latter bound twice as much proteins (Table 1). Guajardo et al. (Guajardo, Bernal, Wilson \& Cabrera, 2015) also reported lower activity of CALB immobilized on heterofunctional supports: octyl-silica-epoxy and undecanol-Sepharose-glyoxyl, than on monofunctional carriers: octyl-silica and octyl-Sepharose, and the same trend was also reported when CALB-on-octyl-agarose-glyoxyl system was compared with that of CALB-on-octyl-agarose (Hirata et al., 2016). Most likely, additional covalent links of the hydrophobic support with the lipase attached in its open/active form, stabilized the system thus preventing enzyme leaching, but they also contributed to an excessive stiffness of the attached protein, which hampered activity (Guajardo, Bernal, Wilson \& Cabrera, 2015; Stauch, Fisher \& Cianci, 2015; Vescovi et al., 2016). Similarly as in the case of hydrolytic reaction, the highest specific activity, i.e. refereed to the amount of attached proteins, featured MH-O-based biocatalyst (Fig. 4B), and that of N435 was only slightly lower, whereas the lipase immobilized on MH-A showed no activity at all. All of the tested catalysts demonstrated very good stability in the esterification of levulinic acid (Fig. 5).

To summarize, N435 emerges as the most effective catalyst for the esterification reaction under study, with a reservation that the reported results apply to the diisopropyl ether as a solvent. If another organic solvent is applied in this or related reaction, we may also expect to observe a Levatit-solvent interaction (cf. Table 2) the final outcome of which, while hard to predict, is likely to be negative from a catalytic perspective. In this respect, the use of MH-O-supported lipase which entails no such problems may be worth considering.

\section{CONCLUSIONS}

The biocatalysts made of the enzyme - lipase, supported on structured siliceous beads functionalized with octyl and amino groups are highly active and stable in organic solvents, in contrast to Novozym 435 which degrades in similar situations. Grafting with both octyl- and amino entities appeared most effective in hydrolytic application - the catalysts were stable and highly active. For reactions in organic solvents structured beads grafted with octyl groups are recommended. The proposed enzyme supports can easily be modified with various functional groups and enzymes, according to the needs, and applied in rotating bed reactors to give highly efficient synthetic systems.

\section{Acknowledgements}


Funding: This work was supported by the by the National Centre for Science - Poland, project UMO2016/23/B/ST8/00627.

\section{Authors contributions}

KS, DG and AJ contributed conception and design of the study. DK did the majority of the experiments. KS and DK established the analytics for this study and analyzed the data; KS DG and AJ wrote the manuscript All authors contributed to manuscript revision, read and approved the submitted version.

\section{REFERENCES}

Aßmann, M., Stobener, A., Gaßmeyer, S.K., Hilterhaus, L., Kourist, R., Liese, A., \& Kara, S. (2017). Reaction engineering of biocatalytic (S)-naproxen synthesis integrating in-line process monitoring by Raman spectroscopy, Reaction Chemistry \& Engineering , 2, 531-540.https://doi.org/10.1039/C7RE00043J.

Aurell, C.J., Karlsson, S., Ponten, F., \& Andersen, S.M. (2014). Lipase catalyzed regioselective lactamization as a key step in the synthesis of N-Boc (2R)-1,4-oxazepane-2-carboxylic acid, Organic Process Research 83 Development , 18, 1116-1119.https://doi.org/10.1021/op5001644.

Bernal, C., Illanes, A., \& Wilson, L., (2014). Heterofunctional Hydrophilic-Hydrophobic Porous Silica Support for Multipoint Covalent Immobilization of Lipases: Application to Lactulose Palmitate Synthesis,Langmuir , 30, 3557-3566.https://doi.org/10.1021/la4047512.

Ciemiega, A., Maresz, K., \& Mrowiec-Białoń, J. (2018). Meervein-Ponndorf-Vereley reduction of carbonyl compounds in monolithic siliceous microreactors doped with Lewis acid centres, Applied Catalysis A: General , 560, 111-118.https://doi.org/10.1016/j.apcata.2018.04.03\%.

Dwivedee, B.P., Bhaumik, J., Rai, S.K., Laha, J.K., \& Banerjee, U.C. (2017). Development of nanobiocatalysts through the immobilization of Pseudomonas fluorescenslipase for applications in efficient kinetic resolution of racemic compounds, Bioresource Technology , 239, 464471.https://doi.org/10.1016/j.biortech.2017.05.050.

Eta, V., Anugwom, I., Virtanen, P., Maki-Arvela, P., \& Mikkola J.P., (2014). Enhanced mass transfer upon switchable ionic liquid mediated wood fractionation, Industrial Crops and Products , 55, 109115.https://doi.org/10.1016/j.indcrop.2014.02.001.

Eta, V., \& Mikkola, J.P., (2016). Deconstruction of Nordic hardwood in switchable ionic liquids and acylation of the dissolved cellulose,Carbohydrate Polymers , 136, 459465.https://doi.org/10.1016/j.carbpol.2015.09.058.

Foukis, A., Gkini, O.A., Stergiou, P.Y., Sakkas, V.A., Dima, A., Boura, K., Koutinas, A., \& Papamicheael, E.M., (2017). Sustainable production of a new generation biofuel by lipase-catalyzed esterification of fatty acids from liquid industrial waste biomass, Bioresource Technology , 238, 122-128. doi: 10.1016/j.biortech.2017.04.028.

Garmroodi, M., Mohammadi, M., Ramazani, A., Ashjari, M., Mohammadi, J., Sabour, B., \& Yousefi, M. (2016). Covalent binding of hyper-activated Rhizomucor miehei lipase (RML) on hetero-functionalized siliceous supports, International Journal of Biological Macromolecules , 86, 208215.https://doi.org/10.1016/j.ijbiomac.2016.01.076.

Goundoju, N.R., Bokam, R., Yalavarthi, N., Shaik, K., \& Ponnapalli, M.G. (2019). Asymmetric total synthesis of 16-methyleicos-(4E)-en-1-yn-3-ol from the marine sponge Cribrochalina vasculum: Establishment of absolute configuration of chiral centers, ChemistrySelect , 4, 399-402.https://doi.org/10.1002/slct.201803646.

Guajardo, N., Bernal, C., Wilson, L. \& Cabrera, Z. (2015). Selectivity of R- $\alpha$-monobenzoate glycerol synthesis catalyzed by Candida antarctica lipase B immobilized on heterofunctional supports, Process Biochemistry , 50, 1870-1877.https://doi.org/10.1016/j.procbio.2015.06.025. 
Gustafsson, H., Thorn, C., \& Holmberg, K. (2011). A comparison of lipase and trypsin encapsulated in mesoporous materials with varying pore sizes and $\mathrm{pH}$ conditions, Colloids and Surface B: Biointerfaces , 87, 464-471.https://doi.org/10.1016/j.colsurfb.2011.06.012.

Hirata, D.B., Albuquerque, T.L., Rueda, N., Virgen-Ortíz, J.J., Tacias-Pascacio, V.G., \& FernandezLafuente, R., (2016). Evaluation of different immobilized lipases in transesterification reactions using tributyrin: Advantages of the heterofunctional octyl agarose beads, Journal of Molecular Catalysis B: Enzymatic , 133, 117-123.https://doi.org/10.1016/j.molcatb.2016.08.008.

Hou, C., Ghéczy, N., Messmer, D., Szymańska, K., Adamcik, J., Mezzenga, R., Jarzebski, A.B., \& Walde, P. (2019). Stable immobilization of enzymes in a macro- and mesoporous silica monolith, ACS Omega , 4, 7795-7806.https://doi.org/10.1021/acsomega.9b00286.

Huang, W., Zhu, N., Liu, Y., Wang, J., Zhoung, J., Sun, Q., Sun, T., Hu, X., Fang, Z. \& Guo, K. (2019). A novel microfluidic enzyme-organocatalysis combination strategy for ring-opening copolymerizations of lactone, lactide and cyclic carbonate, Chemical Engineering Journal , 365, 592597.https://doi.org/10.1016/j.cej.2018.09.033.

Hudson, S., Cooney, J., \& Magner, E. (2008). Proteins in mesoporous silicates, Angewandte Chemie International Edition 47, 8582-8594.http://dx.doi.org/10.1002/anie.200705238.Immobilized

Jiang, Y.J., Zheng, P.J., Zhou, L.Y., Kong, W., Gao, J., Wang, J., Gu, J., Zhang, X., \& Wang, X. (2016). Immobilization of lipase in hierarchically ordered macroporous/mesoporous silica with improved catalytic performance, Journal of Molecular Catalysis B: Enzymatic, 130, 96103.https://doi.org/10.1016/j.molcatb.2016.05.009.

Jose, C., \& Briand, L. E. (2010). Deactivation of Novozym@ 435 during the esterification of ibuprofen with ethanol: Evidences of the detrimental effect of the alcohol, Reaction Kinetics, Mechanism and Catalysis , 99, 17-22.https://doi.org/10.1007/s11144-009-0103-4.

Jose, C., Bonetto, R. D., Gambaro, L. A., Torres, M. P., Foresti M. L., Ferreira, M. L., \& Briand, L.E. (2011). Investigation of the causes of deactivation-degradation of the commercial biocatalyst Novozym 435 in ethanol and ethanol-aqueous media, Journal of Molecular Catalysis B: Enzymatic , 71, 95107.https://doi.org/10.1016/j.molcatb.2011.04.004.

Karbowiak, T., Saada, M.A., Rigolet, S., Ballandras, A., Weber, G., Bezverkhyy, I., Soulard, M., Patarin, J., \& Bellat, J.P. (2010). New insights in the formation of silanol defects in silicalite-1 by water intrusion under high pressure, Physical Chemistry Chemical Physics , 12, 11454-11466.https://doi.org/10.1039/c000931h.

Lima, L.N., Oliveira, G.C., Rojas, M.J., Castro, H.F., Da Ros, P.C.M., Mendes, A.A., Giordano, R.L.C., \& Tardioli, P.W. (2015). Immobilization of Pseudomonas fluorescens lipase on hydrophobic supports and application in biodiesel synthesis by transesterification of vegetable oils in solvent-free systems, Journal of Industrial Microbiology \& Biotechnology , 42, 523-535.https://doi.org/10.1007/s10295-015-1586-9.

Mallin, M., Muschiol, J., Byström. E., \& Bornscheuer, U. T. (2013). Efficient biocatalysis with immobilized enzymes or encapsulated whole cell microorganism by using the SpinChem reactor system, ChemCatChem , 5, 3529-3532.https://doi.org/10.1002/cctc.201300599.

Odrozek, K., Szymańska, K., Lewanczuk, M., Dzido, G., Pudło, W., Bryjak, J., \& Jarzebski, A.B. (2017). Aerobic enzymatic oxidation of benzoic acid derivatives in a rotating bed reactor with hierarchically structured packing, Przemyst Chemiczny, 96, 2446-2449.https://doi.org/10.15199/62.2017.12.7.

Ortiz, C., Ferreira, M.L., Barbosa, O., dos Santos, J.C.S., Rodrigues, R.C., Berenguer-Murcia, Á., Briand, L.E., \& Fernendez-Lafuente, R. (2019). Novozyme 435: the "perfect" immobilized biocatalyst?,Catalysis Science \& Technology , 9, 2380-2420.https://doi.org/10.1039/C9CY00415G.

Pham, T.N., Samikannu, A., Rautio, A.R., Juhasz, K.L., Konya, Z., Warna, J., Kordas, \& K., Mikkola, J.P. (2016). Catalytic hydrogenation of D-xylose over Ru decorated carbon foam catalyst in a SpinChem $\mathbb{R}$. 
rotating bed reactor, Topics in Catalysis , 59, 1165-1177.https://doi.org/10.1007/s11244-016-0637-4.

Stauch, B., Fisher, S.J., \& Cianci, M. (2015). Open and closed states of Candida Antarctica lipase B: protonation and the mechanism of interfacial activation, Journal of Lipid Research , 56(12) 2348-2358. doi: 10.1194/jlr.M063388

Strub, D. J., Szymańska, K., Hrydziuszko, Z., Bryjak, J., \& Jarzebski, A.B. (2019) Continuous flow kinetic resolution of a non-equimolar mixture of diastereoisomeric alcohol using a structured monolithic enzymatic microreactor, Reaction Chemistry \& Engineering , 4, 587-594. https://doi.org/10.1039/C8RE00177D .

Szymańska, K., Bryjak, J., Mrowiec-Białon, J., \& Jarzebski, A.B. (2007). Application and properties of siliceous mesostructured cellular foams as enzymes carriers to obtain efficient biocatalysts, Microporous and Mesoporous Materials, 99, 167-175.https://doi.org/10.1016/j.micromeso.2006.08.035 .

Szymańska, K., Pudło, W., Mrowiec-Białoń, J., Czardybon, A., Kocurek, J., \& Jarzebski, A.B. (2013). Immobilization of invertase on silica monoliths with hierarchical pore structure to obtain continuous flow enzymatic microreactors of high performance, Microporous and Mesoporous Materials, 170, 7582.https://doi.org/10.1016/j.micromeso.2012.11.037.

${ }^{a}$ Szymańska, K., Odrozek, K. Zniszczoł, A., Torrelo, G., Resch, V., Hanefeld, U., \& Jarzebski, A.B. (2016). MsAcT in siliceous monolithic microreactor enables quantitative ester synthesis in water, Catalysis Science E Technology, 6, 4882-4888.https://doi.org/10.1039/C5CY02067K .

bSzymańska, K., Pietrowska, M., Kocurek, J., Maresz, K., Koreniuk, A., Mrowiec-Białoń, J., Widlak, P., Magner, E., \& Jarzebski, A. (2016). Low back-pressure hierarchically structured multichannel microfluidic bioreactors for rapid protein digestion - Proof of concept, Chemical Engineering Journal , 287, 148154.https://doi.org/10.1016/j.cej.2015.10.120 .

Szymańska, K., Odrozek, K., Zniszczoł, A., Pudło, W., \& Jarzebski, A.B. (2017). A novel hierarchically structured siliceous packing to boost the performance of rotating bed enzymatic reactor, Chemical Engineering Journal, 315, 18-24.https://doi.org/10.1016/j.cej.2016.12.131 .

Tang, W., Wang, X., Huang, J., Jin, Q., \& Wang, X. (2015). A novel method for the synthesis of symmetrical triacylglycerols by enzymatic transesterification, Bioresource Technology ,. 196, 559565.https://doi.org/10.1016/j.biortech.2015 .

Thomas, J.C., Burich, M.D., Bandeira, P.T., Marques de Oliveira, A.R., \& Piovan, L. (2017). Biocatalysis in continuous-flow mode: A case study in the enzymatic kinetic resolution of secondary alcohols via acylation and deacylation reactions mediated by Novozym 435@, Biocatalysis , 3, 27-36. https://doi.org/10.1515/boca2017-0003 .

van der Helm, M.P., Bracco, P., Busch, H., Szymańska, K., Jarzebski, A.B., \& Hanefeld, U. (2019). Hydroxynitrile lyases covalently immobilized in continuous flow microreactors, Catalysis Science 83 Technology , 9, 1189-1200. https://doi.org/10.1039/C8CY02192A .

Vescovi, V., Kopp, W., Guisan, J.M., Giordano, R.L.C., Mendes, A.A., \& Tardioli, P.W. (2016). Improved catalytic properties of Candida antartica lipase B multi-attached on tailor-made hydrophobic silica containing octyl and multifunctional amino-aldehyde spacer arms,Process Biochemistry , 51, 20552066.https://doi.org/10.1016/j.procbio.2016.09.016 .

Wang, J., Gu, S.S., Cui, H.S., Wu, X.Y., \& Wu, F.A. (2014). A novel continuous flow biosynthesis of caffeic acid phenethyl ester from alkyl caffeate and phenethanol in a packed bed microreactor, Bioresource Technology , 158, 39-47.https://doi.org/10.1016/j.biortech.2014.01.145 .

Wang, J., Liu, X., Wang, X.D., Dong, T., Zhao, X.Y., Zhu, D., Mei, Y.Y., \& Wu, G.H. (2016). Selective synthesis of human milk fat-style structured triglycerides from microalgal oil in a microfluidic reactor packed with immobilized lipase, Bioresource Technology , 220, 132-141. https://doi.org/10.1016/j.biortech.2016.08.023 
Wang, Y., Zhang, X., Han, N., Wu, Y., \& Wei, D. (2018). Oriented covalent immobilizatation of recombinant protein on the glutaraldehyde activated agarose support, International Journal of Biological Macromolecules , 120, 100-108.https://doi.org/10.1016/j.ijbiomac.2018.08.074.

Xu, J., Liu, C., Wang, M., Shao, L., Deng, L., Nie, K., \& Wang, F. (2017). Rotating packed bed reactor for enzymatic synthesis of biodiesel, Bioresource Technology , 224 (2017) 292297.https://doi.org/10.1016/j.biortech.2016.10.045 .

Zare, M., Golmakani, M.T., \& Niakousari, M. (2019). Lipase synthesis of isoamyl acetate using different acyl donors: Comparison of novel esterification techniques, LWT-Food Science and Technology, 101, 214-219. https://doi.org/10.1016/j.lwt.2018.10.098 .

Zhao, H., \& Song, Z. (2010). Migration of reactive trace compounds from Novozym@ 435 into organic solvents and ionic liquids, Biochemical Engineering Journal , 49 (2010) 113118.https://doi.org/10.1016/j.bej.2009.12.004 .

Zhou, L., He, Y., Ma, L., Jiang, Y., Huang, Z., Yin, L., \& Gao, J. (2018). Conversion of levulinic acid into alkyl levulinates: Using lipase immobilized on meso-molding three-dimensional macroporous organosilica as catalyst, Bioresour. Technol. 247, 568-575. https://doi.org/10.1016/j.biortech.2017.08.134.

of interfacial activation, Journal of Lipid Research , 56, 2348-2358. https://doi.org/10.1194/jlr.M063388 .

Table 1. Properties of the siliceous-enzyme carriers and the biocatalysts obtained.

Table 2. Pore structure parameters of N435 and relative activity of N435 and MH catalysts after $24 \mathrm{~h}$ incubation in organic solvents.

Fig. 1. Hg porosimetry plots and SEM images of the applied silica pellets (MH) and Novozym 435.

Fig. 2. Activity (A) and specific activity (B) of MH-catalysts and Novozym 435 (N435) in hydrolysis of p-nitrophenyl acetate.

Fig. 3. Stability of MH-catalysts and Novozym 435 (N435) in hydrolysis of p-nitrophenyl acetate in four runs.

Fig. 4. Activity (A) and specific activity (B) of MH-catalysts and Novozym 435 (N435) in esterification of levulinic acid with n-butanol.

Fig. 5. Stability of MH-catalysts and Novozym 435 (N435) in esterification of levulinic acid with n-butanol.

Table 1. Properties of the siliceous-enzyme carriers and the biocatalysts obtained.

\begin{tabular}{|c|c|c|c|c|c|c|}
\hline Carrier & $\mathbf{S}_{\mathrm{BET}}\left[\mathbf{m}^{2} / \mathrm{g}\right]$ & $\begin{array}{l}\mathrm{C} / \mathrm{H} / \mathrm{N} \\
{[\mathrm{m} \%]}\end{array}$ & $\begin{array}{l}\text { Amount of } \\
\text { functional } \\
\text { groups } \\
{\left[\mathrm{mmol} / \mathrm{g}_{\text {silica }}\right]}\end{array}$ & $\begin{array}{l}\text { Hydrophobicity } \\
{\left[\mathbf{m g}_{\text {dye }} /\right.} \\
\left.\mathrm{g}_{\text {silica }}\right]\end{array}$ & $\begin{array}{l}\mathrm{y} \\
\text { Protein load } \\
{\left[\mathrm{mg}_{\text {protein }} / \mathrm{g}_{\text {silica }}\right.}\end{array}$ & $\begin{array}{l}\text { Immobil. } \\
\text { aYield [\%] }\end{array}$ \\
\hline MH & 310 & - & - & $0.0149 \pm 0.0014$ & - & - \\
\hline MH-A & 154 & $2,62 / 1,24 / 0,82$ & 0.6 & $0.2329 \pm 0.0082$ & $19.4^{\mathrm{b}}$ & 56.0 \\
\hline MH-O & 290 & $2,53 / 1,26 /-$ & 0.27 & $0.1329 \pm 0.0039$ & $15.3^{\mathrm{b}}$ & 44.3 \\
\hline MH-OA & 208 & $4,32 / 1,31 / 0,74$ & $\begin{array}{l}0.5(\mathrm{~A}) ; 0.25 \\
(\mathrm{O})\end{array}$ & $0.3105 \pm 0.0010$ & $27.0^{\mathrm{b}}$ & 78.4 \\
\hline N435 & 59 & - & - & - & $64.8^{\mathrm{a}}$ & - \\
\hline
\end{tabular}

aProtein was desorbed using Triton-X and next its concentration was determined by Lowry method

${ }^{\mathrm{b}}$ Measured by Lowry method 


\begin{tabular}{|c|c|c|c|c|c|c|}
\hline Solvent & & $\begin{array}{l}\text { Novozym } \\
435\end{array}$ & $\begin{array}{l}\text { Novozym } \\
435\end{array}$ & $\begin{array}{l}\text { Novozym } \\
435\end{array}$ & MH-O & MH-OA \\
\hline- & $\begin{array}{l}\mathrm{V}_{\text {tot. }[\mathrm{Hg}]^{*}}{ }^{*} \\
\left.\mathrm{~cm}^{3} / \mathrm{g}\right] \\
1.21\end{array}$ & $\begin{array}{l}\mathbf{S}_{\mathrm{BET}}{ }^{* *} \\
{\left[\mathbf{m}^{2} / \mathrm{g}\right]} \\
59\end{array}$ & $\begin{array}{l}\mathbf{V}_{\text {mesp.[N2] }} \\
{\left[\mathbf{c m}^{3} / \mathrm{g}\right]} \\
0.48\end{array}$ & $\begin{array}{l}\text { Relative } \\
\text { activity } \\
1.00\end{array}$ & $\begin{array}{l}\text { Relative } \\
\text { activity } \\
1.00\end{array}$ & $\begin{array}{l}\text { Relative } \\
\text { activity } \\
1.00\end{array}$ \\
\hline $\begin{array}{l}\text { Ethyl } \\
\text { acetate }\end{array}$ & 0.53 & - & - & $0.22 \pm 0.01$ & $1.00 \pm 0.05$ & $0.66 \pm 0.01$ \\
\hline Hexane & - & 67 & 0.51 & $1.00 \pm 0.12$ & $1.00 \pm 0.01$ & $1.00 \pm 0.01$ \\
\hline Butanol & 0.36 & 11 & 0.08 & $0.87 \pm 0.06$ & $1.00 \pm 0.05$ & $0.86 \pm 0.02$ \\
\hline Acetone & - & 3 & 0.07 & $0.84 \pm 0.06$ & $0.87 \pm 0.03$ & $0.97 \pm 0.00$ \\
\hline $\begin{array}{l}\text { Diisopropyl } \\
\text { ether }\end{array}$ & 0.99 & 53 & 0.53 & $0.97 \pm 0.18$ & $1.00 \pm 0.08$ & $0.92 \pm 0.10$ \\
\hline Acetonitrile & 0.37 & 1 & 0.07 & $0.72 \pm 0.04$ & $0.95 \pm 0.03$ & $0.83 \pm 0.11$ \\
\hline Toluene & - & - & - & $1.00 \pm 0.03$ & $0.97 \pm 0.12$ & $0.98 \pm 0.08$ \\
\hline Chloroform & - & - & - & $1.00 \pm 0.04$ & $0.95 \pm 0.01$ & $0.91 \pm 0.00$ \\
\hline
\end{tabular}

Table 2. Pore structure parameters of N435 and relative activity of N435 and MH catalysts after $24 \mathrm{~h}$ incubation in organic solvents.

${ }^{*} \mathrm{Hg}$ porosimetry for selected samples

** For Novozym 435 incubated in ethyl acetate, toluene and chloroform low temperature nitrogen adsorption measurements were not carried out because of degassing problems

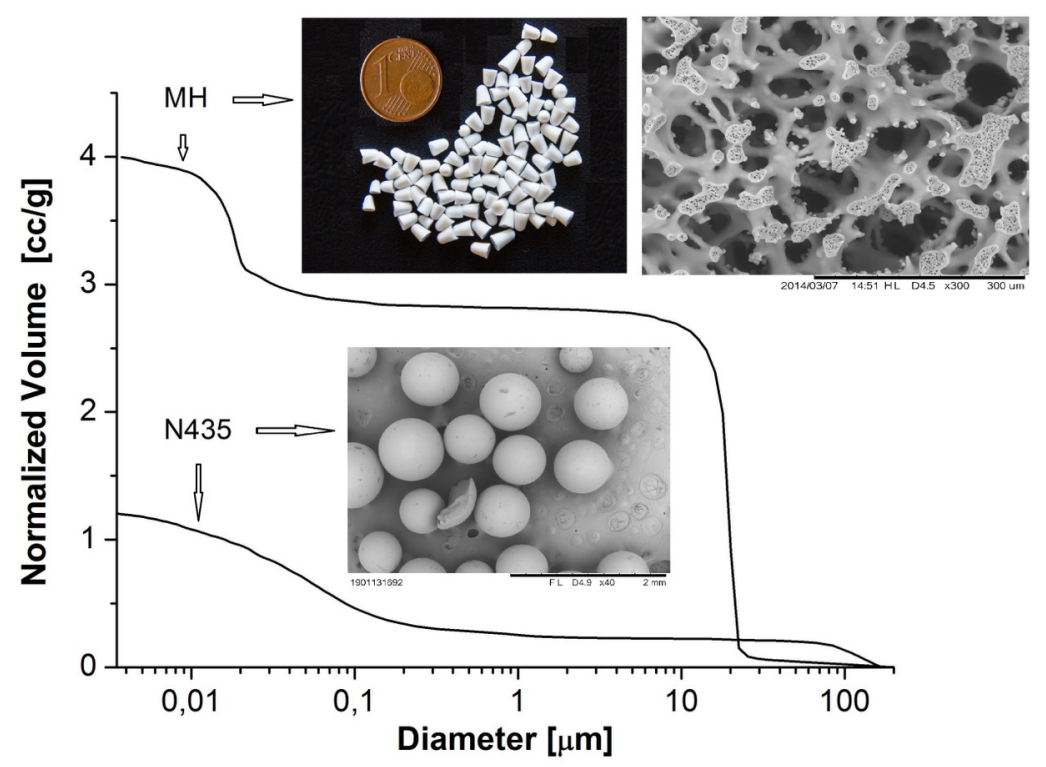

Fig. 1. Hg porosimetry plots and SEM images of the applied silica pellets (MH) and Novozym 435. 

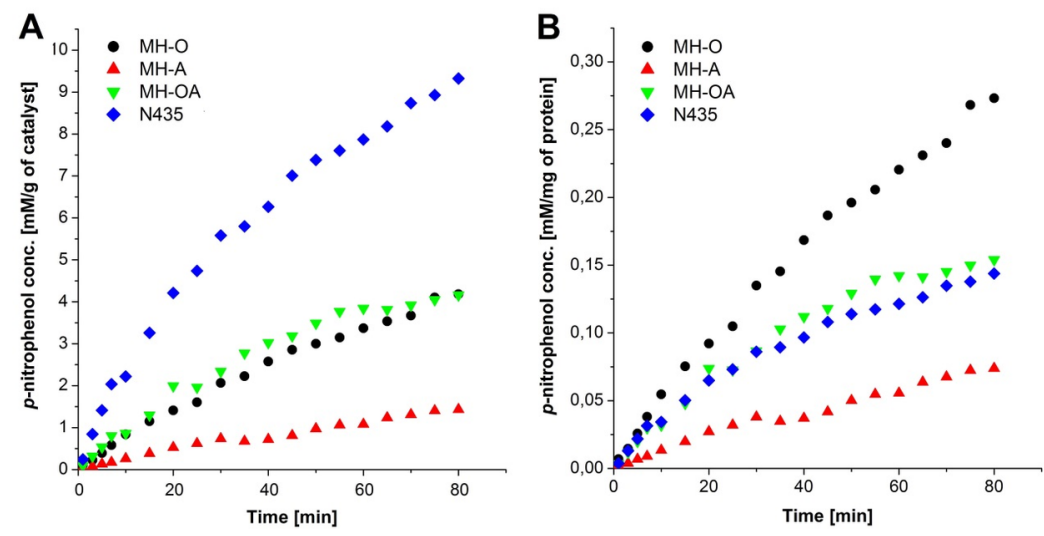

Fig. 2. Activity (A) and specific activity (B) of MH-catalysts and Novozym 435 (N435) in hydrolysis of p-nitrophenyl acetate.
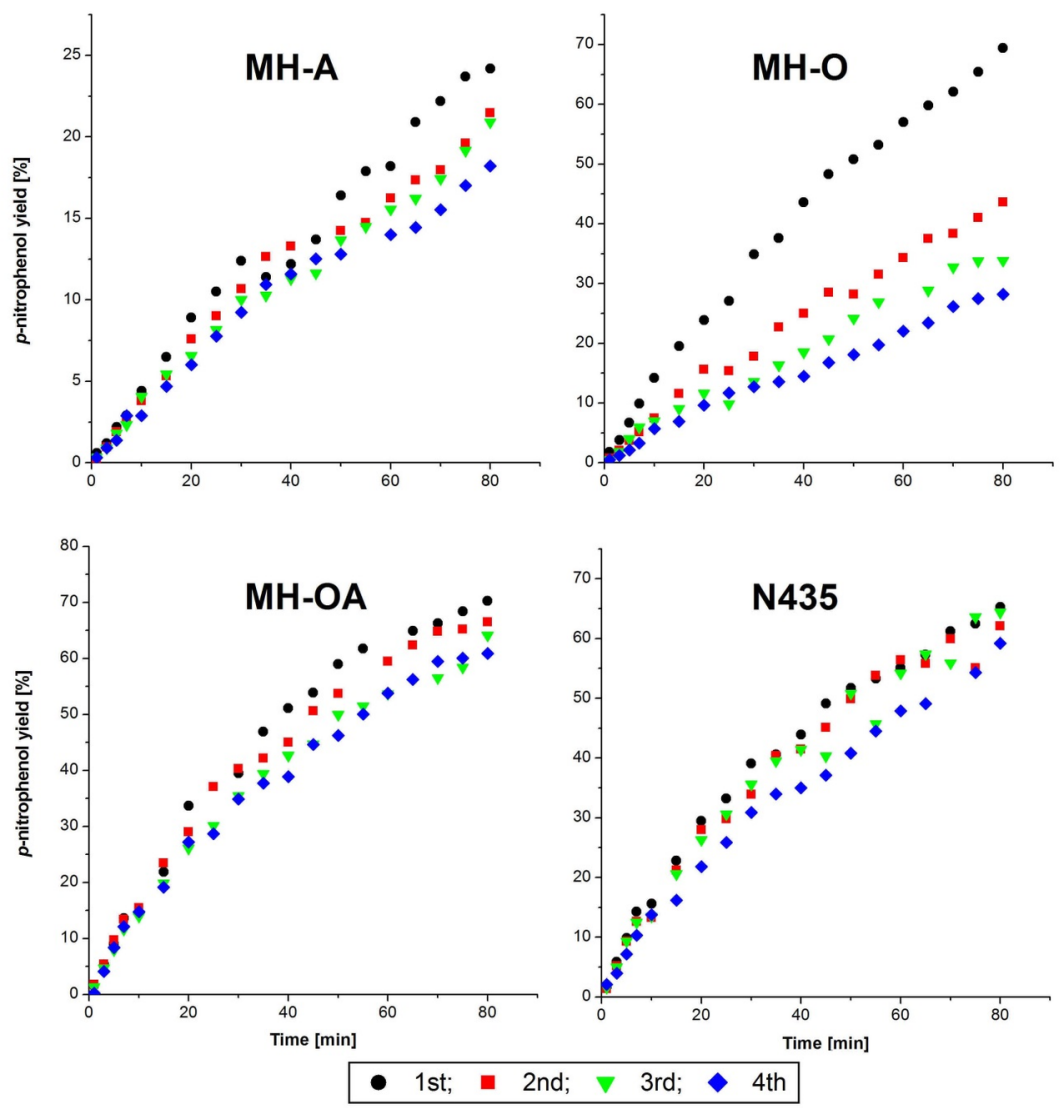

Fig. 3. Stability of MH-catalysts and Novozym 435 (N435) in hydrolysis of p-nitrophenyl acetate in four runs. 

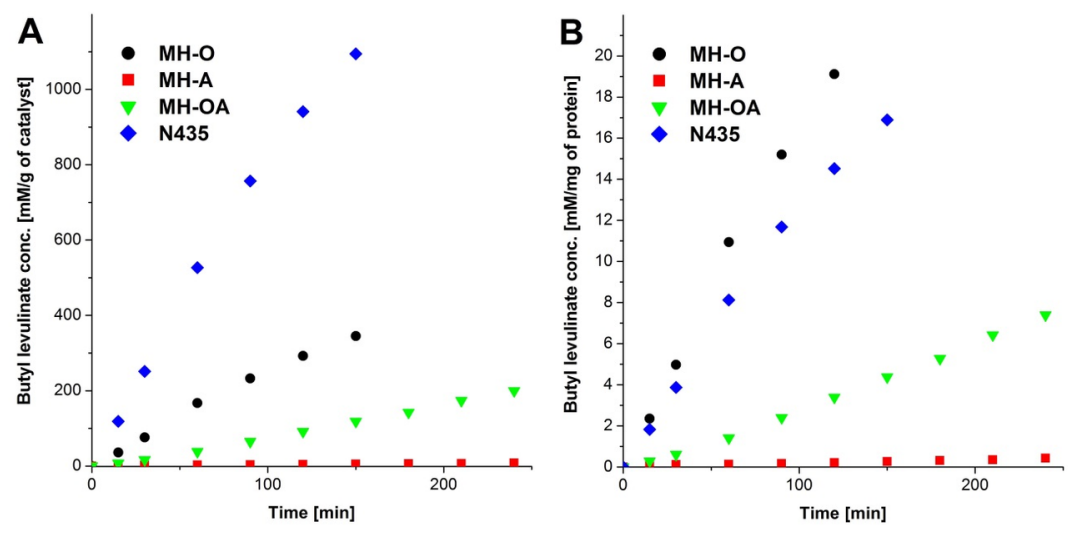

Fig. 4. Activity (A) and specific activity (B) of MH-catalysts and Novozym 435 (N435) in esterification of levulinic acid with n-butanol.
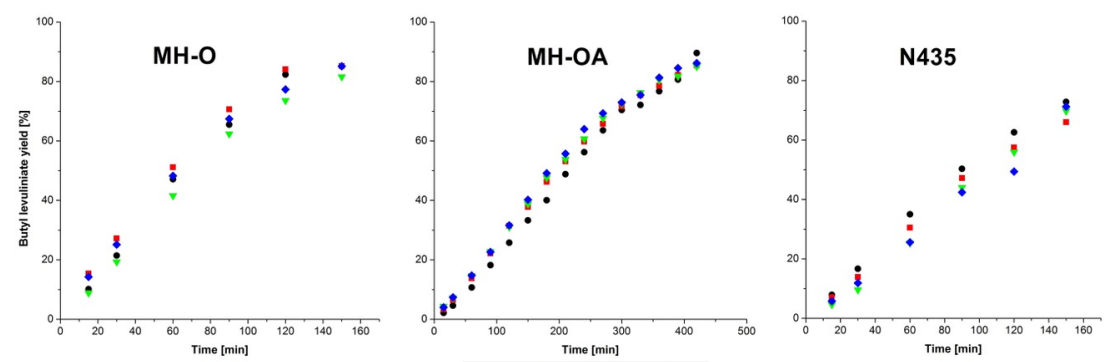

- 1st; - 2nd; $\nabla$ 3rd; $\bullet$ 4th

Fig. 5. Stability of MH-catalysts and Novozym 435 (N435) in esterification of levulinic acid with n-butanol.

\section{Hosted file}

Table1.docx available at https://authorea.com/users/347906/articles/473402-rotating-bedreactor-packed-with-heterofunctional-structured-silica-supported-lipase-or-novozym-435developing-an-effective-system-for-the-organic-solvent-and-aqueous-phase-reactions

\section{Hosted file}

Table2.docx available at https://authorea.com/users/347906/articles/473402-rotating-bedreactor-packed-with-heterofunctional-structured-silica-supported-lipase-or-novozym-435developing-an-effective-system-for-the-organic-solvent-and-aqueous-phase-reactions 

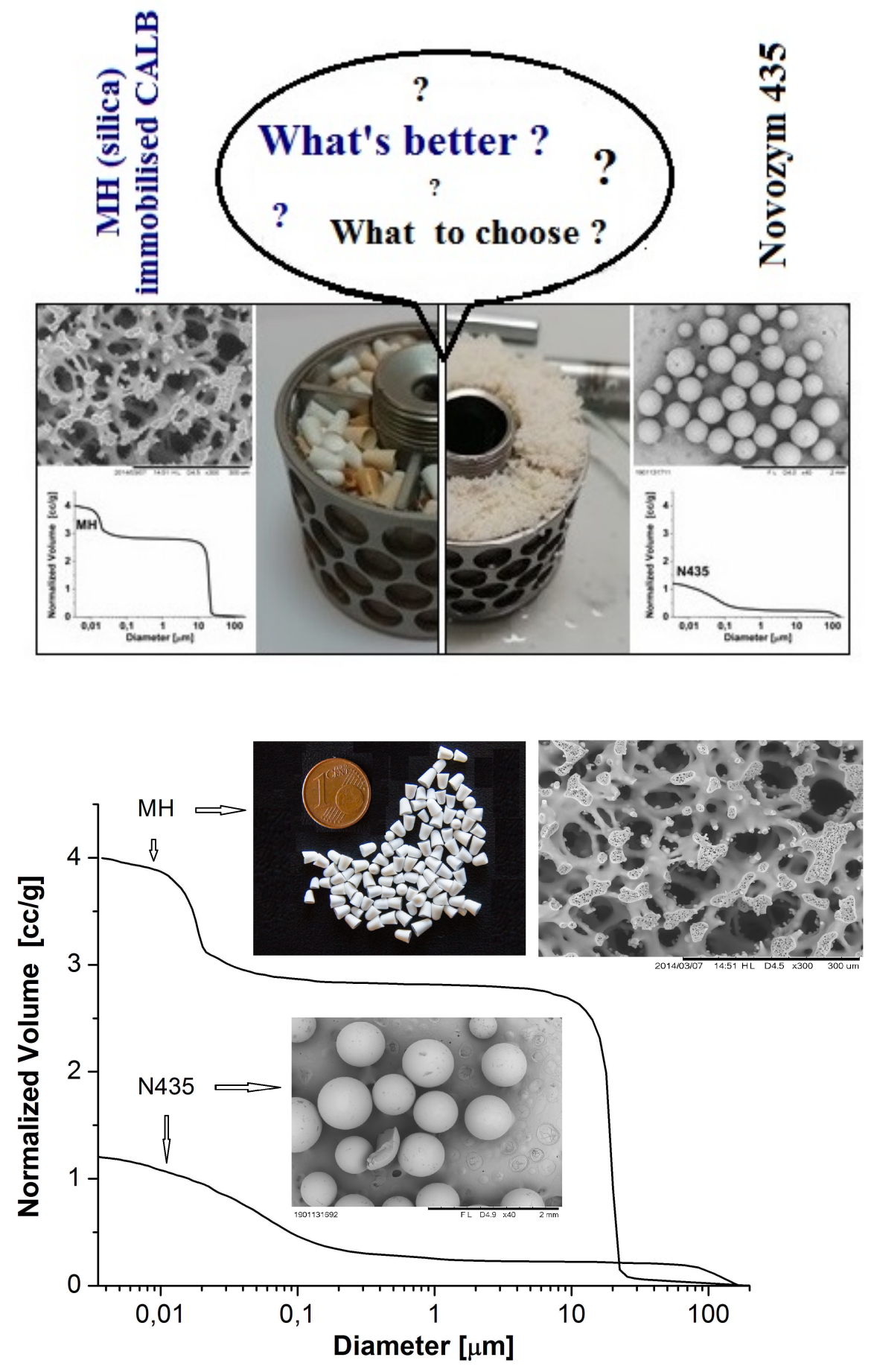

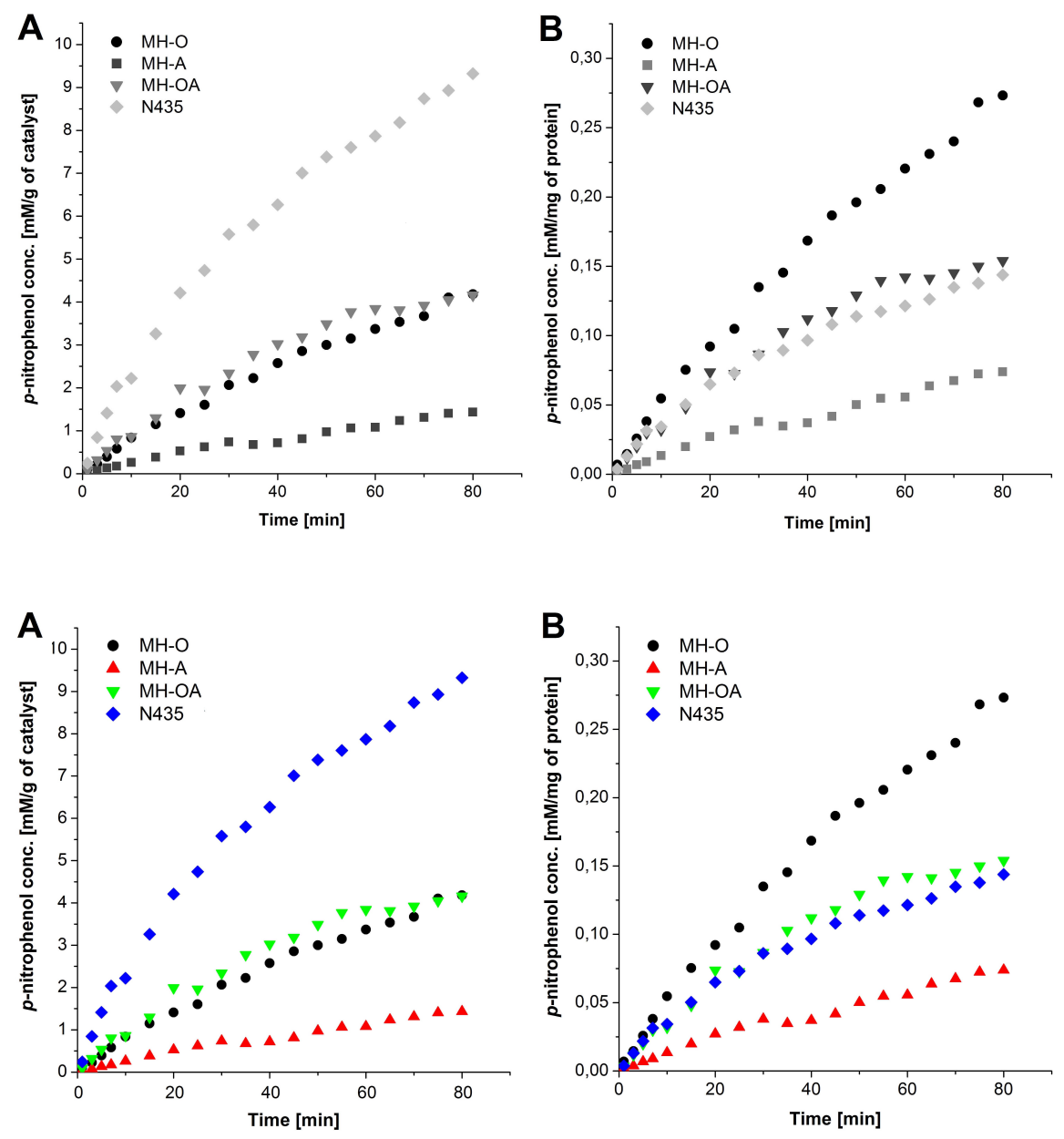

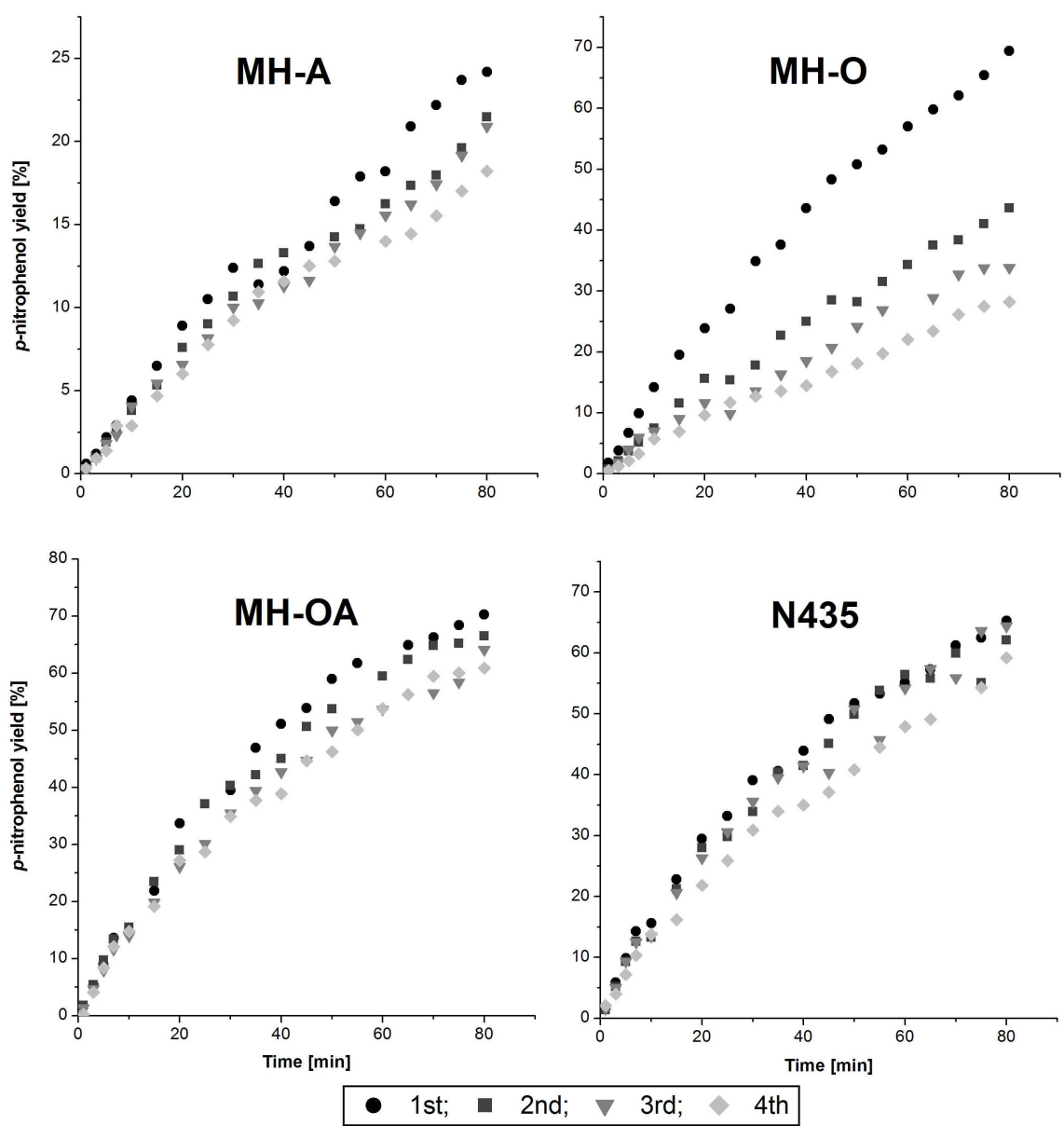

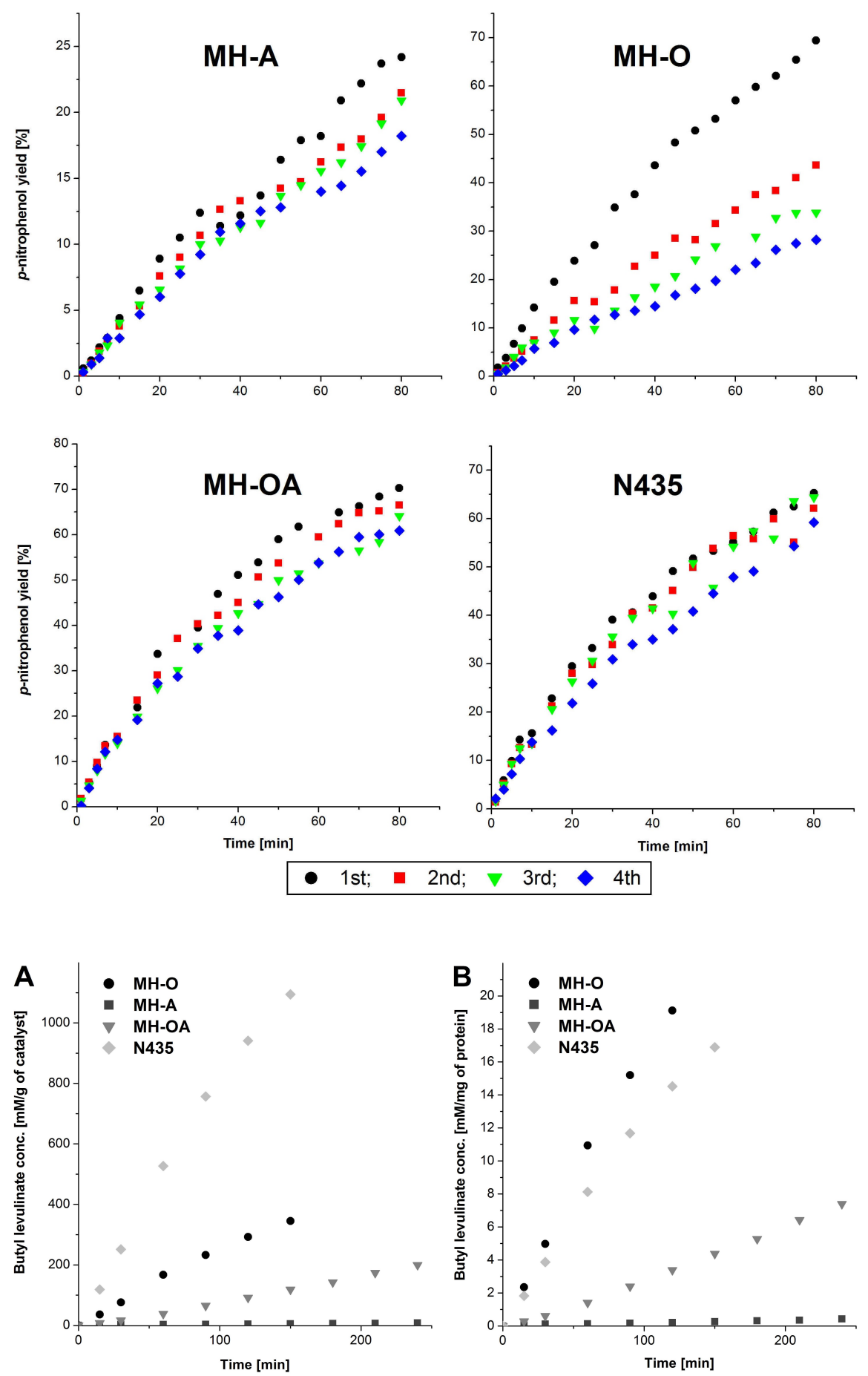

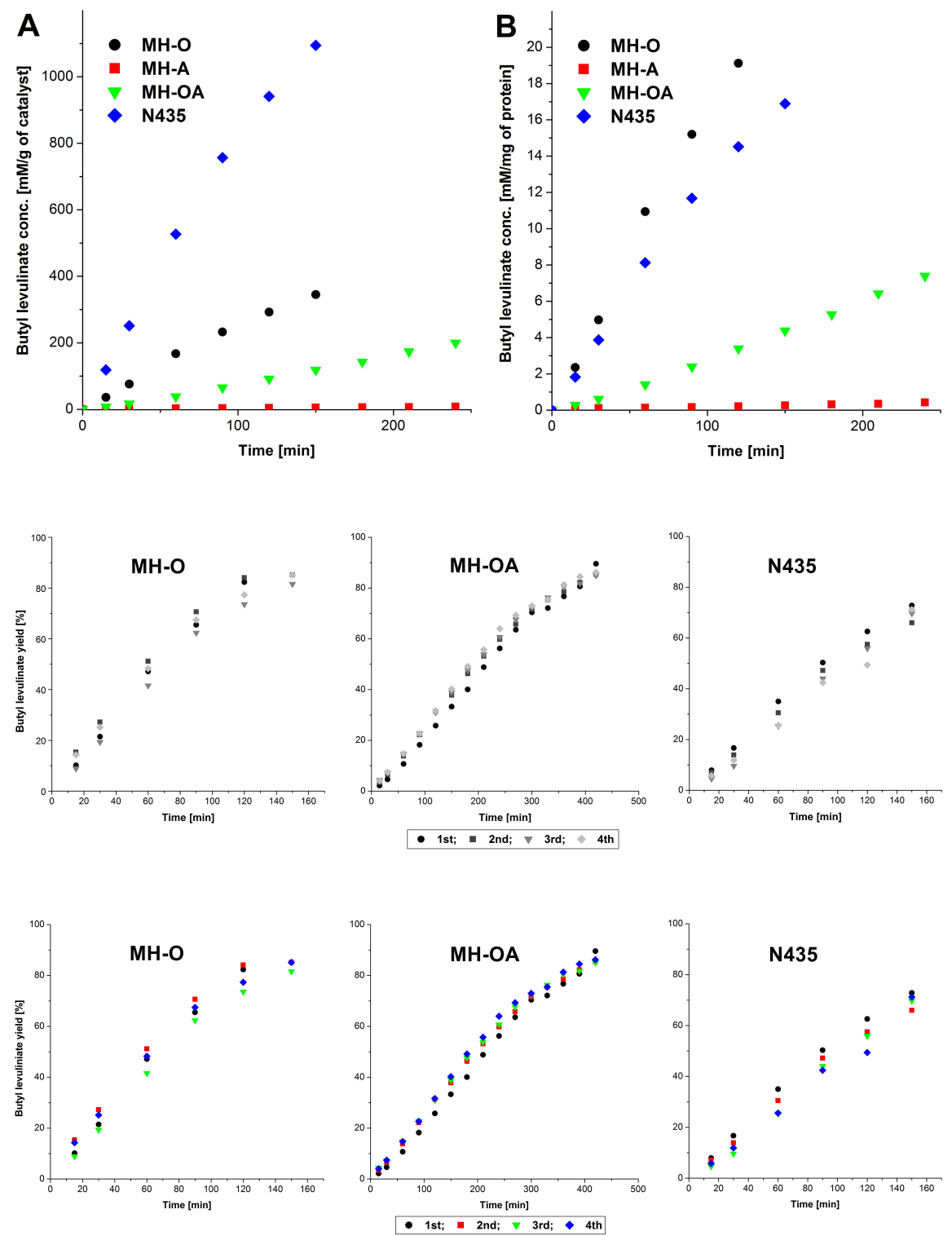